\section{Cotton Fiber as a Substitute for Agar Support in Tissue Culture}

\author{
Rita M. Moraes-Cerdeira \\ Research Institute of Pharmaceutical Sciences, The University of Mississippi, \\ MS 38677
}

Jeffrey V. Krans
Department of Plantand Soil Sciences, Mississippi State University, Mississippi
State, MS 39762

James D. McChesney

Research Institute of Pharmaceutical Sciences, The University of Mississippi, MS 38677

Ana M.S. Pereira and Suzelei C. Franca
Setor de Biotecnologia Vegetal-Universidade de Ribeirao Preto, Ribeirao
Preto, SP, Brazil

Additional index words. medium support, shoot cultures, callus maintenance, organogenesis, Agrostis stolonifera var. Palustris, Taxus $\times$ media cv. Hicksii, Artemisia annua

\begin{abstract}
Cotton fibers were tested as a substitute for agar in tissue culture. The cost of agar has prompted us to search for an alternative more economical medium support. Effectiveness as a medium support was evaluated in terms of callus maintenance and shoot organogenesis using Artemisia, Agrostis, and Taxus. Taxus and Agrostis calli cultivated on liquid media with cotton fiber as medium support ( $25 \mathrm{ml}$ of medium per gram of cotton) grew better than calli on agar $(0.8 \% \mathrm{w} / \mathrm{v})$. There were no significant differences in shoot organogenesis of Artemisia and Agrostis grown in $25 \mathrm{ml}$ of medium per gram of cotton from those grown in agar medium.
\end{abstract}

Although most plant tissues can grow well in liquid media, a semisolid medium is recommended for use under some circumstances. Since 1943, agar has been widely used as a tissue culture support (White, 1943). According to Romberger and Tabor (1971), contaminants present in agar can be released and affect the culture of plant tissues. Starch copolymer (Cook, 1977), fabric tissue (100\% polyester) (Cheng and Voqui, 1977), filter paper platforms (Horsch et al., 1980), glass fiber (Tabor, 1981), and gellan gum (Eyre and Caswell, 1991) have been reported as alternatives to agar. In Brazil, agar support is an expensive component of tissue culture medium. In the present study, rolled cotton fiber was tested as a possible substitute for agar because it is readily available and at a low cost (U.S. $\$ 19.00 /$ $\mathrm{kg}$ ). To our knowledge, cotton has not been reported as a medium support for plant tissue cultures. The objectives of this research were to compare agar and cotton support for callus maintenance and clonal propagation using several species (Artemisia annua L., Agrostis stolonifera var. palustris Farwell, Taxus $\times m e$ dia Rehd cv. Hicksii).

\footnotetext{
Received for publication 6 Sept. 1994. Accepted for publication 11 Apr. 1995. The cost of publishing this paper was defrayed in part by the payment of page charges. Under postal regulations, this paper therefore must be hereby marked advertisement solely to indicate this fact.
}

\section{Materials and Methods}

Callus induction and maintenance. Callus initiation and growth of Agrostis were according to Blanche et al. (1986). Seeds were surface-disinfected in $0.5 \% \mathrm{NaOCl}(10 \% \mathrm{v} / \mathrm{v}$ clorox) solution with four drops of Tween 20 for $20 \mathrm{~min}$. Treated seeds were rinsed in sterile distilled water and then cultured on MS salts (Murashige and Skoog, 1962), 3\% (w/v) sucrose, $4.5 \mu \mathrm{M}$ 2,4-dichlorophenoxyacetic acid (2,4-D), $0.8 \%$ (w/v) Sigma type E agar (Sigma Chemical Co., St. Louis). The medium was adjusted to $\mathrm{pH}$ 5.7. Cultures were incubated in darkness and subcultured four times (8-week intervals) before the experiment.

Agrostis callus (200 to $250 \mathrm{mg} / \mathrm{vessel}$ ) was cultured on $25,16.7$, and $10.9 \mathrm{ml}$ medium per gram of rolled cotton (Johnson and Johnson, Skilmmann, N.J.) and $0.8 \%$ (w/v) type E agar and incubated in darkness. Cotton used in this study was $100 \%$ pure, sterile, nonchlorinebleached rolled fiber manufactured according to USP specifications. Cotton fiber $(1.2 \mathrm{~g})$ was compressed, placed in glass culture vessels (4 $\mathrm{cm}$ diameter $\times 9.5 \mathrm{~cm}$ high, baby food jars with Magenta B cap), and sterilized. Sterile me$\operatorname{dium}(30,20$, or $13 \mathrm{ml})$ was poured into vessels containing the sterilized cotton fibers. Agaramended sterile medium $(25 \mathrm{ml})$ was dispensed into each vessel. Callus was transferred to cotton- or agar-supported medium. The experiments were replicated five times in a completely randomized design. This experiment was conducted twice. Growth was mea- sured 4 weeks later as fresh weight increase.

Callus growth in Taxus was modified from Fett-Netto et al. (1992). Young stem segments of Taxus $\times$ media cv. Hicksii were collected from 26.5-liter potted plants that were $1.0 \mathrm{~m}$ tall (Cottage Gardens, Lansing, Mich.). In July 1993, stem segments (6 to $8 \mathrm{~mm}$ long) were collected and surfaced disinfected with $1.03 \% \mathrm{NaOCl}[20 \%(\mathrm{v} / \mathrm{v})$ Clorox (Clorox Corp., Cleveland)] solution, plus four drops of Tween 20, for $20 \mathrm{~min}$. Treated explants were rinsed three times in sterile distilled water and cultured in MS medium with $4.5 \mu \mathrm{M}$ 2,4-D. The $\mathrm{pH}$ was adjusted to 5.7. The cultures were incubated under fluorescent lights with photon flux of $\approx 52 \mu \mathrm{mol} \cdot \mathrm{m}^{-2} \cdot \mathrm{s}^{-1}$ for a 16 -h photoperiod at $25 \pm 2 \mathrm{C}$. Calli started to develop on the cut portions of the explants not immersed in the medium. Apparently, the calli developed from the cambium and outer parenchyma stem cells. Cultures were subcultured before the study.

Taxus callus growth was maintained on B5 salts (Gambor et al., 1968) supplemented with $18.1 \mu \mathrm{M}$ 2,4-D, $4.6 \mu \mathrm{m}$ kinetin, and 1\% (w/v) polyvinylpyrrolidone (PVP-10) (Fett-Neto et al., 1992). Taxus callus (270 to $305 \mathrm{mg} / \mathrm{vessel}$ ) was then subcultured to this medium using cotton and agar support previously described. The cultures were incubated for 30 days. Callus growth was measured by fresh weight increase. Each treatment had five replications and the experiment was conducted twice.

Shoot organogenesis. Nodal and apical segments ( 3 to $5 \mathrm{~mm}$ ) were collected from Artemisia plants cultivated in the Medicinal Plant Garden at the Research Institute of Pharmaceutical Sciences, Univ. of Mississippi. The explants were surface-disinfected in $1.03 \%$ $\mathrm{NaOCl}[20 \%$ (v/v) Clorox] solution plus four drops of Tween 20 for $10 \mathrm{~min}$ and then rinsed three times in sterile distilled water.

Shoot cultures in Artemisia were modified from Nair et al. (1986). The explants were cultured on MS salts, with $30 \mathrm{~g}$ of sucrose, 2.3 $\mu \mathrm{M}$ kinetin, $1.1 \mu_{\mathrm{M}}$ indole-3-acetic acid (IAA), and cotton $(25,16.7$, or $10.9 \mathrm{ml}$ medium per gram of cotton) and agar support. The $\mathrm{pH}$ was adjusted to 5.8. Cultures were incubated for 30 days under the same conditions described previously. After the incubation period, the number of microshoots derived from the axillary buds was recorded. Artemisia microshoots were rooted in MS medium to confirm viability. Each treatment was replicated four times and the experiment was conducted three times.

Nodal segments $(3 \mathrm{~mm})$ of differentiated plantlets were excised from shoots derived from Agrostis calli (Blanche et al., 1986). Explants were cultured on MS half-strength salt medium with cotton $(25,16.7$, or $10.9 \mathrm{ml}$ medium per gram of cotton) and $0.8 \%$ agar as medium support, and $30 \mathrm{~g}$ of sucrose. The $\mathrm{pH}$ was adjusted to 5.7. The cultures were incubated under the same environment conditions as Artemisia shoot cultures. After an incubation period of 30 days, the number of shoots was recorded. All analyses on callus fresh weight increases in Agrostis and Taxus and shoot cultures of Artemisia and Agrostis were performed using SAS (1985). 


\section{Results and Discussion}

Growth of Agrostis and Taxus calli on cotton support with $25 \mathrm{ml}$ medium per gram of cotton was superior to that on agar (Table 1). The higher amounts of callus growth of Taxus and Agrostis on cotton may be due to better nutrient diffusion on cotton than agar, and/or due to agar impurities, as suggested by Romberger and Tabor (1971). However, the refinement of type E agar used in this study lessens the potential for callus injury due to impurities.

Microshoot formation of Agrostis and Artemisia was similar whether cotton at $25 \mathrm{ml}$ medium per gram or agar was used as support for the explants. Both species was affected by the degree of cotton saturation (Table 1). For Agrostis shoot culture, there was no statistical difference between agar-supported cultures and cotton support. However, when $10.9 \mathrm{ml}$ of medium was added to cotton, the number of shoots induced decreased by more than half. Shoot formation in Artemisia was significantly reduced with less medium applied on cotton.

In terms of callus growth and microshoot proliferation, cotton was a suitable substitute for agar for tissue culture of Taxus, Agrostis, and Artemisia, provided sufficient medium was applied to the cotton. Root induction on Artemisia and Agrostis was unaffected by medium support. Presence of roots was noticed in microshoots of both species after 30 days of culturing on either support. According to Cheng and Voqui (1980), the use of fabric tissue ( $100 \%$ polyester) facilitates periodic changes of the medium without transfer of the cultured tissues, and this also may be true for cultures using cotton support. Minimal disturbance of callus culture and reproducibility were the basis of the filter paper growth assay technique of Horsh et al. (1980). This study

Table 1. Cotton or agar as supports for callus growth and shoot formation in cultures of Agrostis, Taxus, and Artemisia.

\begin{tabular}{|c|c|c|c|c|c|}
\hline \multirow[b]{3}{*}{ Genus } & \multicolumn{4}{|c|}{ Support } & \multirow{3}{*}{$\begin{array}{l}\text { Dunnett's } \\
(P \leq 0.05\end{array}$} \\
\hline & \multicolumn{3}{|c|}{$\begin{array}{c}\text { Cotton } \\
\text { (ml of medium } / \mathrm{g} \text { of cotton) }\end{array}$} & \multirow{2}{*}{$\begin{array}{c}\begin{array}{c}\text { Agar } \\
(\% \mathrm{w} / \mathrm{v})\end{array} \\
0.8\end{array}$} & \\
\hline & 10.9 & 16.7 & 25 & & \\
\hline \multicolumn{6}{|c|}{ Callus growth } \\
\hline \multicolumn{6}{|c|}{ Increase in fresh weight ( $\mathrm{g} /$ culture) } \\
\hline Agrostis & $0.20^{*}$ & 0.48 & $0.64^{*}$ & 0.41 & 0.18 \\
\hline Taxus & $0.10^{*}$ & 0.39 & $0.78^{*}$ & 0.37 & 0.16 \\
\hline \multicolumn{6}{|c|}{ Organogenesis } \\
\hline \multicolumn{6}{|c|}{ No. shoots/explant } \\
\hline Agrostis & 2.0 & 5.0 & 4.7 & 4.2 & 2.8 \\
\hline Artemisia & $1.1^{*}$ & $4.4^{*}$ & 9.2 & 9.8 & 2.7 \\
\hline
\end{tabular}

*Indicates cotton treatments that differ from agar treatment at $P \leq 0.05$ using Dunnett's test.

shows that cotton can be used for callus growth and very precise data also may be obtained with the same benefit. However, each plant species and use should be tested to verify advantages or disadvantages.

\section{Literature Cited}

Blanche, F.C., J.V. Krans, and G.E. Coats. 1986. Improvement of callus growth and plantlet formation in creeping bentgrass. Crop Sci. 26:12451248

Cheng, T.Y. and T.H. Voqui. 1977. Regeneration of Douglas fir plantlets through tissue culture. Science 198:306-307.

Cook, R.C. 1977. The use of an agar substitute in initial growth of Boston ferns in vitro. HortScience 12:339.

Eyre, M.J. and E.P. Caswell. 1991. Sterile culture of Rotylenchulus reniformis on tomato root with gellan gum as a supporting medium. J. Nematol. 23:229-231.

Facchini, P.J. and F. DiCosmo. 1991. Plant cell bioreactor for the production of protoberberine alkaloids from immobilized Thalictrum rugosum cultures. Biotechnol. \& Bioeng. 37:397-403.

Fett-Netto, A., F. DiCosmo, W.F. Reynolds, and K.
Sakata. 1992. Cell culture of Taxus as a source of the antineoplastic drug taxol and related taxanes. Bio/Technology 10:1572-1575.

Gamborg, O.L., R.A. Miller, and K. Ojima. 1968. Nutrient requirements of suspension cultures of soybean root cells. Expt. Cell. Res. 50:151-158.

Horsch, R.B., J. King, and G.E. Jones. 1980. Measurements of cultured plant cell growth on filter paper discs. Can. J. Bot. 58:2402-2406.

Murashige, T. and F. Skoog. 1962. A revised medium for rapid growth and bioassay with tobacco tissue culture. Physiol. Plant. 15:473497.

Nair, M.S.R., N. Acton, and D. Klayman. 1986 Production of artemisinin in tissue cultures of Artemisia аппиа. J. Natural Prod. 49:504-507.

Romberger, J.A. and C.A. Tabor. 1971. The Picea abies shoot apical meristem in culture. I. Agar and autoclaving effects. Amer. J. Bot. 58:131140 .

SAS Institute. 1985. SAS/STAT user's guide. Release 6.03 ed. SAS Inst., Cary, N.C.

Tabor, C.A. 1981. Improving the suitability of glass fiber filters for use as cultures supports. In Vitro 17:129-132.

White, P.R. 1943. A handbook of plant tissue culture. Ronald Press Co., New York. 